\title{
Special issue of Medicinal Chemistry Research in honor of Professor Gary L. Grunewald
}

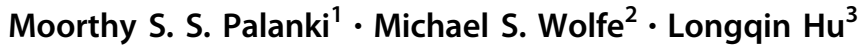

Accepted: 2 June 2021 / Published online: 18 June 2021

This is a U.S. government work and not under copyright protection in the U.S.; foreign copyright protection may apply 2021

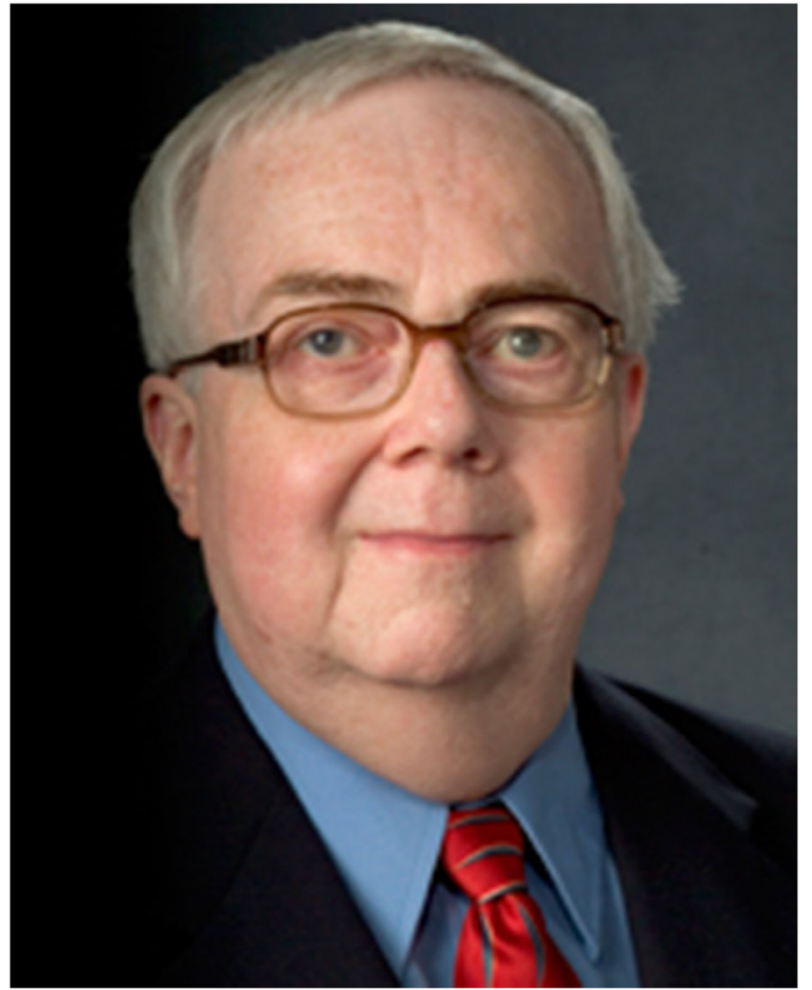

This issue of Medicinal Chemistry Research is dedicated to Professor Gary L. Grunewald for his many years of dedication to research, education, and service in the Department of Medicinal Chemistry and School of Pharmacy at the University of Kansas (KU) and his many years of dedicated

Moorthy S. S. Palanki

mpalanki@csusm.edu

1 Department of Biological Sciences, California State University San Marcos, San Marcos, CA 92096, USA

2 Department of Medicinal Chemistry, School of Pharmacy, The University of Kansas, Lawrence, KS 66045, USA

3 Department of Medicinal Chemistry, Ernest Mario School of Pharmacy, Rutgers, The State University of New Jersey, Piscataway, NJ 08854, USA service to the broader scientific community, including serving in various leadership roles in the American Chemical Society (ACS) Division of Medicinal Chemistry, American Heart Association, the Academy of Pharmaceutical Sciences, and the American Association for the Advancement of Science.

As a Washington native, Gary double-majored in chemistry and pharmacy at Washington State University. After graduation from college with the highest honors in 1960, he joined the University of Wisconsin for his Ph.D. in organic chemistry while receiving a Wisconsin Alumni Research Foundation Fellowship and a NIH predoctoral fellowship. His Ph.D. dissertation under the guidance of Prof. Howard Zimmerman was focused on the chemistry of barrelene and photochemical conversion of barrelene to semibullvalene, which was known to be the first example of the di-pimethane rearrangement. 
In 1965, as he was finishing up his Ph.D. work and exploring his options, Gary was very much interested in pursuing postdoctoral training under the distinguished Professor Edward E. Smissman at the KU. When he was offered a postdoctoral position with Professor Smissman in the spring of 1965 as he was completing his doctoral research and writing his dissertation, he eagerly accepted it.

Gary was invited by Professor Smissman to visit Lawrence in the Fall of 1965. He was met by Professor Smissman at the old Kansas airport. On the drive to Lawrence, Professor Smissman loquaciously described the rolling hills, beautiful scenery, and welcoming culture of eastern Kansas. The following day, Gary met with faculty and students from the Department of Medicinal Chemistry as well as the Department of Chemistry. Later that day, Professor Smissman asked Gary to give an informal chalk talk. The next morning when Gary met Professor Smissman in his office, he was asked whether he really wanted to come to KU as a post-doc or "wouldn't you rather come here as an assistant professor?" Unbeknownst to Gary, he was being interviewed for a faculty position! Apparently, the excellent performance Gary gave the day before was so convincing that he was offered the faculty position on the spot. In this surprising way (which has not been repeated since), Gary started his long distinguished academic career in January 1966 along with his first group of four graduate students that fall that included Bharat Kamdar (M.S., 1968), Ann Warner (Ph.D., 1970), Winton D. Jones, Jr. (PhD, 1970), and Dale Mirth (Ph.D., 1971), and became the longest-serving faculty member to date in the Department of Medicinal Chemistry at KU School of Pharmacy.

Gary's research as a professor focused on studying threedimensional shape of potential drug molecules and their interaction with biological targets such as receptors and enzymes. A biologically active molecule with flexible bonds would have a number of different conformations at various energy levels, and one specific conformation-that may not be the lowest energy-is likely preferred by its biological target. A different conformation may be responsible for side effects through its interaction with an offtarget site. Professor Grunewald's research focused on improving the selectivity and potency of potential drug molecules by synthesizing their rigid analogs where the lead is "locked" into conformationally restricted or conformationally defined systems. This approach provided insights into the conformational requirements of binding to the active site of an enzyme or ligand-binding site of a receptor. Professor Grunewald pioneered the use of this approach to develop conformationally restricted and defined analogs of epinephrine as inhibitors of phenylethanolamine $\mathrm{N}$-methyltransferase (PNMT), facilitating the study of the role of this catecholamine in the central nervous system.
In the early 1980s, Professor Grunewald recognized the importance of computer-aided drug design (CADD) in drug discovery and development. He spearheaded efforts to bring the first computer to the Department of Medicinal Chemistry at $\mathrm{KU}$ for molecular modeling work, which paved the way for the department to grow in several leading areas in research and education in medicinal chemistry. The first computer from Evans and Sutherland provided both hardware and software to view 3-D structures of biologically active molecules and their macromolecular targets on the screen. As the department continued to grow, this early entry into the computer era paved the way for the department to enter into the molecular modeling arena that benefitted many research projects and the training of graduate students and postdocs. This entry into computer-assisted modeling later helped the department to build a Chemical Methodologies and Library Development Research Center that was funded for many years by NIH. This center allowed medicinal chemists to design analogs and perform parallel synthesis to quickly identify novel molecules with potential drug-like properties. This early entry into CADD arena also helped to build a strong bioinformatics program at KU. In mid 1980s, when the department purchased its first $300 \mathrm{MHz}$ and later a 500-MHz NMR instrument, Gary quickly realized the potential application of NMR studies in understanding the bound conformation of compounds to their protein targets. He successfully used the $500-\mathrm{MHz}$ NMR instrument to determine the bound conformation of inhibitors at the active site of PNMT, which paved the way for the design of better inhibitors. Gary published over 140 peer-reviewed papers and 100 posters/abstracts describing his research work. He was a guest editor for Medicinal Research Series. Altogether, Professor Grunewald can be thought of as the father of CADD and bioinformatics research in the Department of Medicinal Chemistry at KU.

In addition to teaching both undergraduate and graduate classes, and conducting research with graduate students and postdocs in his lab, Professor Grunewald also served the larger scientific community through several additional leadership roles. He was chairman of the Department of Medicinal Chemistry from 1994 to 2003 and an interim dean of KU School of Pharmacy from 1993 to 1994. He also served the ACS Division of Medicinal Chemistry (MEDI) in various capacities including as a member of its Long-range Planning Committee (1991-1994), as Vice Chair and Chair (1993-1994) of the Division, and as a Councilor (1999-2001). He served as general chair of the 27th National Medicinal Chemistry Symposium in 2000, as Chair of the Research Committee (1983-85) and as a member of the Board of Directors (1980-1991) of the Kansas Affiliate of the American Heart Association. He also served as Chair of the Medicinal Chemistry and Pharmacognosy Section of the Academy of Pharmaceutical 
Sciences (1983) and as Chair of the Pharmaceutical Sciences Section of the American Association for the Advancement of Science (1994). He served on the Editorial Advisory Boards for Bioorganic and Medicinal Chemistry and Bioorganic and Medicinal Chemistry Letters. He was selected as a Fellow of the American Association of Pharmaceutical Scientists (2006), a Fellow of the ACS (2010), and was an inaugural member of the Division of Medicinal Chemistry Hall of Fame (2006).

Training future scientists along with research was one of Professor Grunewald's passions. He felt it was important to provide research opportunities to undergraduates and help them decide whether they would like to pursue a Ph.D. degree. This would help foster passion for research at the undergraduate level. He initiated Undergraduate Research Participation program with funding from NSF. This program identified undergraduates interested in doing research from not only Kansas but also neighboring states like Nebraska, Iowa, and Oklahoma — and beyond. Later on, this program was renamed the Research Experience for Undergraduates and would continue to grow with funding from NSF. A number of undergraduates went through the program and became very successful in their chosen path including as professors in academia, research scientists in industry, and writers/columnists for chemical societies. This commitment to education extended to the graduate student population as well. Gary was one of the biggest supporters of the Medicinal Chemistry Meetings-in-Miniature held annually among the Universities of Minnesota, Iowa, Kansas, and Illinois/Chicago (hence the better known name of the "MIKI" meetings).

Kansas is among the few states that recognized early on the importance of medical professionals to have continuing education (CE); as such, they made $\mathrm{CE}$ a requirement for doctors, pharmacists, and other medical professionals to renew their professional license. As one can imagine, many pharmacists live and practice in remote parts of Kansas, and it is very difficult for them to travel to satisfy their CE requirements. In order to provide them an opportunity to earn CE credits, Professor Grunewald (along with his colleague Prof. Hanzlik) would travel to various parts of Kansas and provided classes for pharmacists so that they could earn CE credits. Since most of the pharmacists were only available on Sundays to take the class, Gary spent his Sundays traveling and providing pharmacists with seminars and education materials.

Gary also felt that it is equally important to recognize his fellow colleagues and their accomplishments. He spent considerable amount of time filling out paperwork, writing support letters, and providing persuasive context to help his colleagues, coworkers, and students to win awards and recognitions that they justly deserved. In addition to his generosity and supportiveness, he wrote and obtained an
NIH grant to renovate the old laboratories in Malott Hall. These renovations helped several research groups.

Gary received accolades including Roland T. Lakey Lectureship Award, Wayne State University (1991); Elected a Fellow of the American Association for the Advancement of Science (1992); the Tripos Associates Award (1995), Taito Soine Memorial Lecture Award at the University of Minnesota (1996); Higuchi Research Achievement Award; the Dolph C. Simons, Sr. Award for Research in the Biomedical Sciences at KU (1996), and the Lester A. Mitscher Faculty Fellowship in Medicinal Chemistry (2013). Gary attained Fellow status in three prestigious learned societies: the American Association for the Advancement of Science (1992), the American Association of Pharmaceutical Scientists (2006), and the ACS (2010). He also received several teaching awards at KU, including the School of Pharmacy (Rho Chi Honor Society) Outstanding Teacher Award (1978), the KU Center for Teaching Excellence Recognition for Excellence in Undergraduate Teaching (2002), and a Rho Chi Teaching Award (2013).

Professor Grunewald personally trained over 60 graduate students, postdoctoral fellows, and undergraduate research participants throughout his career but influenced the lives of countless more. All of us who worked with him treasured the training that we received in his lab. His passion for science, devotion to the program, rigor in conducting research, desire for helping students, and dedication to the success of the department has left a lasting impression and influence on all of us. He was instrumental in identifying and hiring young faculty members and provided strong support to young faculty as they were trying to establish themselves. He is a true Jayhawk, showing undying devotion to the KU-aside from the Med Chem department, he is a passionate supporter of its basketball program - and to the science of medicinal chemistry as a whole.

His generosity is a reflection of his core belief that "anyone's success is everyone's success." His character and beliefs nurtured a collegiate spirit in the Department of Medicinal Chemistry at KU, a legacy of his that persists today. Dr Dale Boger, who started his first academic position at KU Department of Medicinal Chemistry and is now the Richard and Alice Cramer Chair of Chemistry at Skaggs Institute for Chemical Biology, summarized it best when he said that "Gary Grunewald was the master of the department's organization and direction." Through this issue, it is our honor and pleasure to recognize Prof. Gary Grunewald for his accomplishments and to thank him for all he has done for our community.

P.S. As a closing tribute, we include the following testimonial from Gary's earliest doctoral students.

Gary L. Grunewald-research mentor

The first year 
Gary arrived at the KU in 1966, a newly minted $\mathrm{PhD}$ in Physical Organic Chemistry. He joined three other faculty members in the relatively new Department of Medicinal Chemistry where he worked cooperatively to create an atmosphere where any highly motivated student would be able to succeed. Nine students entered the Ph.D. graduate program that year, and three of us, Winton Jones, Dale Mirth, and Ann Warner chose Gary as our major professor. It was an act of faith on all our parts, not least Gary's. He had, after all, mere weeks before, been a student himself.

Winton came to KU from Butler with an M.S. in pharmacy with a pharmacology concentration. He chose a photochemical project involving barrelene that extended Gary's doctoral research into the photochemical conversion of barrelene to semibullvalene, the first recognized example of the di-pi-methane rearrangement. Dale, with a B.S. in chemistry from Penn State, and Ann, with a B.S. in chemistry from Marymount College of Kansas, chose Gary because they were intrigued by the unique chemical structures he was proposing as potential antiviral agents, namely analogs of aminoadamantane (Dale) and aziridines and [10] annulenes (Ann).

Having a sufficient number of excellent ideas to attract three students in his first year as a faculty member was a feat all its own. Winton, the only African American student in the department at that time, Dale, and Ann, who was one of only two women, quickly learned that they'd chosen wisely. As a major professor, Gary was as dedicated to our success as we were, and he offered us the mentoring that would stand us in good stead the rest of our varied careers. He demanded excellence, effort, and integrity. His door was always open to us, and in addition, he followed our progress closely with unscheduled visits to our laboratories. Even when he was extensively correcting our research reports- he always insisted on the meticulous attention to detail-he was helping to instill in us independence and a belief in our own competence and abilities.

Although all of us ended up in positions that used little of the specific training we'd undergone at KU, we nevertheless had, with Gary's help, developed the confidence to be able to take on unexpected professional roles and both survive and thrive. Winton, as one of the early African American chemists working in drug discovery, took a position with William S Merrell Company in Cincinnati, Ohio, which then became Sanofi-Aventis. Later, he joined Discovery Chemistry at Eli Lilly in Indianapolis, Indiana. $\mathrm{He}$ is the co-inventor on forty-seven US patents and contributed to the selection of five drug candidates for clinical studies. Ann directed clinical laboratories at Lahey Clinic, the University of Puerto Rico, and the University of Cincinnati, ending up as one of the few female professors in the College of Medicine at the University of Cincinnati. Dale spent his career at the National Institute of Dental Research of the National Institutes of Health as a research chemist synthesizing compounds and improving delivery methods for the prevention of dental caries and periodontal disease and as a project scientist overseeing contracted research.

We are convinced that our successes in this variety of positions owed a great deal to the experiences we had as Gary's students at KU, and we are grateful for his guidance, empathy, and encouragement during and after our time there. Further, we are delighted to have been the experimental models for all those who followed.

Ann Warner, Ph.D.-September, 1970

Winton D. Jones, Jr., Ph.D.-December, 1970

Dale Mirth, Ph.D._-August, 1971 